\title{
THE ISSUE OF COGNITIVE PROCESSES IN PRIMARY AGED CHILD
}

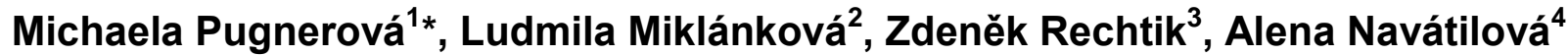 \\ ${ }^{1}$ Dr. Department of Psychology and Abnormal Psychology, Faculty of Education, Palacky \\ University in Olomouc, CZECH REPUBLIC, email: michaela.pugnerova@upol.cz \\ ${ }^{2}$ Assoc. Prof., Department of Primary and Pre-primary Education, Faculty of Education, Palacky \\ University in Olomouc, CZECH REPUBLIC, email: ludmila.miklankova@upol.cz \\ ${ }^{3}$ Mr., Department of Primary and Pre-primary Education, Faculty of Education, Palacky University \\ in Olomouc, CZECH REPUBLIC, email: zdenek.rechtik@upol.cz \\ ${ }^{4}$ Ms., Department of Primary and Pre-primary Education, Faculty of Education, Palacky University \\ in Olomouc, CZECH REPUBLIC, email: alinavratilova@email.cz \\ ${ }^{*}$ Corresponding Author
}

\begin{abstract}
The aim of the presented paper was to map and analyze the quality of some cognitive processes in primary school children. Cognitive processes are understood here in the sense of the so-called "fluid intelligence", which is not tied to school education and which is a fundamental construct of the child's inclusion in the peer group, contributing significantly to the quality of life not only in the school environment. The subject of the research is a description and subsequent analysis of cognitive processes, which are understood by some authors as an important and supporting construct of the so-called executive functions (some authors do not divide these two components and work with them as a whole). Data were collected by standardized Czech version of Cognitive Ability Test (CAT) (Thorndike, Hagen, 1997). The research group consisted of 87 primary school children aged $9.57 \pm 0.80$ years. Descriptive statistics, $t$-test, were chosen to evaluate the obtained data. The approval of the Ethics Committee of the authors' workplace was granted for the realization of the research. The results of the research evoke the need to monitor the further development of the monitored variables in relation to the possibilities of stimulation and their improvement regarding the increasing demands of living and educational requirements (digitalization in education, analysis and problem solving, etc.). The study was supported by the project IGA_PdF_2021_017.
\end{abstract}

Keywords: The Cognitive Processes, The Fluid Intelligence, The Primary School Children

\section{INTRODUCTION}

Within the definition of cognitive processes, thinking and intelligence can probably be considered the most complex. As far as thinking is concerned, it is an inner mental action that cannot be directly observed. During the thinking process, there are different ways of manipulating information, processing it and using it. It is influenced socially and connected with speech and intelligence. Thinking is one of the crucial roles in a child's education. Most educators are usually aware of this fact, but some do not know what level of thinking can be expected of a child in a particular age. A number of learning failures are then caused by the fact that the child is not able to apply those forms of thinking that are required from him (Plháková, 2003; Fontana, 2003; Vágnerová, 2007; Hartl, Hartlová, 2015; Křeménková in Pugnerová, 2019). Related to the thinking process is the concept of "thought operations" introduced by Jean Piaget. These are purposeful mental manipulations with psychic contents, which aim to solve a number of theoretical and practical problems (Plháková, 2003). Thought operations can be divided into so-called logical thought operations, which are managed by clear and precise rules that must be followed. They are sometimes referred to as an algorithm (a well-defined procedure or set of rules, consisting of a series of subsequent steps that are a prerequisite for the correct solution). These procedures are used mainly in mathematics, programming (it could be 
assumed that they are an important part of ICT competencies / Töpfer, 1995 /), as well as in formal logic and natural sciences (as a kind of algorithm, however, can be understood as a cooking recipe) (Knuth, 1998; Steven, 2008). Furthermore, there are the so-called heuristic thought operations, which can be defined as informal, speculative and intuitive strategies that help simplify problems and find ways to solve them (Tversky, Kahneman, 2012). These rules say what the individual should focus on and what, on the contrary, does not need attention. Unlike logical operations, they do not guarantee the correctness of the conclusion, as they are associated with a number of errors and distortions to which our cognition is subject. It is assumed that in everyday functioning, people use mainly heuristic procedures (Plháková, 2003; Atkinson, 2003; Vágnerová, 2007).

As for the concept of intelligence, it can be mentioned that in relation to intellectual activity, F. Galton first used the term and thus replaced the term "habilité" (ability) of the French pioneer of intelligence testing A. Binet (Praus, 2008). There are a number of definitions of intelligence; from a general point of view, according to Nakonečný (2015), they can be divided into two important areas. Intelligence is often understood as a general ability to adapt oneself, which coexists with other specific abilities. The second significant category is intelligence as a complex of relatively independent factors of mental performance. However, most experts agree that any definition of intelligence is always controversial in its own way, because the starting points themselves are controversial. Thus, the concept of intelligence covers a wide range from the definition of intelligence only as a disposition to think to a broad definition of intelligence as a disposition to learning (Atkinson, 2003; Sternberg, 2009). Intelligence can also be understood as an internally divided and at the same time global ability of an individual to act effectively, to think reasonably and to cope effectively with his surroundings. Intelligence develops on the basis of the interaction of innate dispositions and stimuli from the external environment. The effect of heredity is assumed to be majority and to be in the range of 50-70\% (Ruissel, 2004). Intelligence is one of the most preferred psychological topics in education, as there are few areas of formal school work that are not affected. At the same time, intelligence often largely determines future social and professional success, ie the process of social and professional assimilation and integration. It is not a static ability and develops during ontogenetic development. The best-known author who has provided valuable knowledge in this area is Jean Piaget (Fontana, 2003; Plháková, 2003; Vágnerová, 2007; Sternberk, 2009). The definition of intelligence as the ability of an effective adaptive reaction of an organism was first mentioned in the 19th century by the philosopher and sociologist Herbert Spencer. The mental performance of an individual began to be systematically examined and measured from the beginning of the 20th century. One of the important theoretical concepts of so-called general intelligence was introduced by Ch. Spearman. He came at the beginning of the 20th century with the statement that there is a general intellectual ability, so-called g-factor, which represents a universal basis on which other cognitive activities depend. In addition to the g-factor, he also considered specific factors, so-called s-factors, on which the remaining differences in the performance of different people depend (he attributed very little importance to the s-factors) (Vágnerová, 2005; Ruissel, 2004; Sterneberk, 2009). R. Cattell introduced the concept of intelligence, where so-called g-factor consists of a crystalline (gc) and a fluid (gf) component. Crystalline intelligence depends on previous experience. It includes knowledge and is also based on the level of vocabulary. Fluid intelligence, on the other hand, represents an innate ability to perceive the world and the relationships in it independently on previous practice or school education, in essence it is the potential to learn and solve problems (Nakonečný, 2009). According to Cattell, fluid intelligence represents the ability to perceive the world and the relationships in it independently on previous specific practice or school education. Fluid intelligence represents the potential of working with abstract symbols and the speed and accuracy of abstract thinking in general. In essence, fluid intelligence is the potential to learn and solve problems. Measurements of this type of intelligence are made possible by tests based on distinguishing significant similarities or differences between unknown or generally known stimuli. All adults who speak their mother tongue know the meaning of words, so their performance depends on the ability to perceive the relationships between them, not on knowing the meanings of words as such (Ruisel, 2000). It is a process that is constantly detected by various psychological diagnostic tools.

The developmental stage of younger school age is usually defined by the time period from 6-7 years to 1011 years, when the first signs of puberty begin to appear (prepubescence). Given that there are significant differences between children at the beginning of compulsory school attendance and children in the higher grades of primary school, some authors (eg Kuric, 1986; Matějček, 1986; Vágnerová, 1999) speak of two stages within the younger school age. They distinguish between younger school age in a narrower sense or early school age (6-8 years) and middle school age (from 8-9 years to 11-12 years) or early adolescence (10-11 / 13 years) (Macek, 2003) or simply a child of younger school age (Říčan, 2004). Psychoanalysis described this period as a period of latency, when one stage of psychosexual development is completed and the basic impulse energy is relatively stable until the beginning of adolescence. According to S. Freud, this is 
a time when sexuality is "latent". This means that both in behavior and in inner life it manifests itself only weakly, covertly, as if its development in this period shifted in place. E. Erikson (2015) aptly described this stage as a period of effort and initiative. The child proves his own value primarily by performance, has a sense of diligence, experiences feelings of tasks division and belonging somewhere. According to the author, the goal of this period is to achieve a sense of competence and self-confidence, as opposed to feelings of failure and inferiority. In this aspect, the subjective experience with the school undoubtedly has a dominant influence. This stage is very important from a perspective professional point of view in that the child acquires a relationship with work and cooperation. The child's experience goes beyond family relationships and is subject to comparison and evaluation in a wider selection of school and extracurricular situations (he must "succeed" outside the family circle). There may be an attempt at rivalry, competition with the environment or, conversely, passivity in behavior or mutilation. The advantages of this period are the possibility to get the feeling that the child is skillful, that he/she can do something, and enjoys it. The disadvantage is that child can acquire a feeling of incompetence and uselessness, suffer from feelings of inferiority and fail to figure out what is actually good at (Erikson, 2015). According to J. Piaget, in the development of cognitive processes, the child is in the stage so-called specific operations, ie. from 7 to 11 years of age. At this stage of development, the complexity of cognition already makes it possible to mentally manipulate the internal representations created in the previous period. Thus, children can perform mental operations related to the world, especially compensation and reversibility. Another significant developmental shift at this stage is the ability to decentralize: the child can now consider multiple aspects of the situation or objects at once. However, a significant limitation of thinking is the fact that operations require the physical presence of objects that the child manipulates. Although the child uses abstract concepts, but only in relation to specific objects (Piaget, 1999; Piaget, Inhelderová, 2014). Similar experiments were performed by Piaget to conserve mass, number, and length He found that mental operations allows children to think about problems in new ways (Atkinson, 2003; Piaget, Inhelder, 2000). Piaget talks about the stage of formal operations for this developmental stage, starting at about the age of 11, when children reach the level of adult thinking. The mental structures of the child are already so developed and internalized that they are usually capable of hypothetical thinking, greater ability of judgement and creativity, the ability to argue over abstract concepts and understanding the world and oneself as a givenness that is unchangeable.

\subsection{Purpose of the Research}

The aim of the presented paper was to map, analyse and reflect on the quality of some cognitive processes in primary school children, which affect the way of orientation (ie understanding), but also the child's behavior. Cognitive processes are understood here in the sense of the so-called "fluid intelligence", which is not tied to school education and which is a fundamental construct of the child's inclusion in the peer group, contributing significantly to the quality of life not only in the school environment.

\subsubsection{Instruments}

Data were collected by standardized Czech version of Cognitive Ability Test (CAT) (Thorndike, Hagen, 1997). The test allows to measure children's abilities to use abstract symbolic relationships and to operate with these relationships. The purpose of the test is to clarify the relationships and flexibility of thinking. Capturing the relationships in different conditions remains the primary task. The test contains three subtests (word battery, numerical battery and picture battery), which are aimed at assessing relational thinking in a situation where the relationships are formulated in word expressions; on the ability to understand quantitative symbols; and to measure fluid intelligence, an ability that is not associated with the level of school education. In the presented research, attention is paid to mapping the results of the last named subtest, ie so-called image battery. The research group consisted of 87 primary school children aged $9.57 \pm 0.80$ years (i.e. 43 girls, age 9,44 $\pm 0,73$ and 44 boys, age 9,70 $\pm 0,85)$. Descriptive statistics and t-test, were chosen to evaluate the obtained data. Data processing was done by statistical software STATISTICA version 13.

\subsubsection{Research Questions}

RQ1: Are there significant differences in the quality of cognitive processes (in the sense of fluid intelligence) in the group of boys and girls?

RQ2: Are there significant differences in the quality of cognitive processes (in the sense of fluid intelligence) in the group of pupils of early school age (8 years) and middle school age (11 years)?

\section{RESULTS}

The starting point for the age definition of the respondents was the periodization of the authors Kuric (1986), Matějček (1986) and Vágnerová (1999), who distinguish between so-called early school age (6-8 years) and 
middle school age (from 8-9 years to 11-12). The theoretical basis for defining the observed variables were authors Thorndike and Hagen (1997), who characterize fluid intelligence as an ability that is not associated with the level of school education. Through subtests (so-called image battery: image classification, image analogy, image synthesis) it is possible to identify the existence of potential for performance, which does not have the possibility of full expression in the school environment.

In the case of RQ1, we were interested in whether there are significant differences in the quality of cognitive processes (in the sense of fluid intelligence) in the group of boys and girls. The analysis of the distribution of individual results confirmed the normal distribution of data and therefore parametric statistics were chosen, especially descriptive statistics and t-test. The tests were performed at the $5 \%$ level of significance.

Table 1. Cognitive processes (image battery-fluid intelligence) in a group of boys and girls $(n=87)$

\begin{tabular}{|l|c|c|c|c|c|}
\hline Variables & $\begin{array}{c}\text { Average } \\
\text { boys }\end{array}$ & $\begin{array}{c}\text { Average } \\
\text { girls }\end{array}$ & $\begin{array}{c}\text { Standard } \\
\text { deviation } \\
\text { boys }\end{array}$ & $\begin{array}{c}\text { Standard } \\
\text { deviation } \\
\text { girls }\end{array}$ & $\mathrm{p}$ \\
\hline O1 & 19,39 & 20,47 & 4,71 & 3,51 & 0,23 \\
\hline O2 & 19,00 & 20,02 & 7,11 & 6,10 & 0,47 \\
\hline O3 & 23,84 & 23,79 & 4,58 & 4,94 & 0,96 \\
\hline HSO & 62,23 & 64,28 & 14,05 & 11,29 & 0,46 \\
\hline SVS & 97,30 & 99,40 & 13,80 & 11,78 & 0,45 \\
\hline
\end{tabular}

Legende: O1: image battery subtest 1, O2: image battery subtest 2, O3: image battery subtest 3 , HSO: rough score of the image battery, SVS: standard age score of the image battery

Tab. 1 presents the results of correlations between individual monitored variables for the entire set of respondents. The results show that a significant relationship between the age of the respondents and cognitive processes (image battery mapping fluid intelligence) was not confirmed, there was no statistical significance.

Table 2. Cognitive processes (image battery-fluid intelligence) in a group of pupils in early school age (8 years) and middle school age (11 years) $(n=17)$

\begin{tabular}{|l|c|c|c|c|c|}
\hline Variables & $\begin{array}{c}\text { Average } \\
8 \text { years } \\
\text { old }\end{array}$ & $\begin{array}{c}\text { Average } \\
11 \\
\text { years } \\
\text { old }\end{array}$ & $\begin{array}{c}\text { Standard } \\
\text { deviation } \\
8 \text { YO }\end{array}$ & $\begin{array}{c}\text { Standard } \\
\text { deviation } \\
11 \text { YO }\end{array}$ & $\mathrm{p}$ \\
\hline O1 & 18,17 & 20,18 & 6,74 & 2,99 & 0,40 \\
\hline O2 & 19,33 & 20,36 & 7,12 & 6,70 & 0,77 \\
\hline O3 & 21,33 & 24,55 & 4,08 & 2,42 & 0,06 \\
\hline HSO & 58,83 & 65,09 & 16,39 & 9,59 & 0,33 \\
\hline SVS & 92,50 & 100,18 & 11,66 & 11,68 & 0,21 \\
\hline
\end{tabular}

Legende: O1: image battery subtest 1, O2: image battery subtest 2, O3: image battery subtest 3 , HSO: rough score of the image battery, SVS: standard age score of the image battery

Tab. 2 presents differences between ages ( 8 and 11 years) in cognitive skills. The results show that a significant relationship between age of respondents ( 8 and 11 years) in cognitive processes (image battery- 
fluid intelligence) was not confirmed, there was no statistical significance.

\section{CONCLUSIONS AND RECOMMENDATIONS}

The results of the research are by no means alarming or surprising, rather they could be summarized in the term "uncomplicated". They evoke the need to continue to monitor the further development of established variables in relation to the possibilities of stimulating and improving cognitive abilities (not only fluid intelligence) with regard to the increasing living and educational requirements of current times (digitalization in education, analysis and problem solving, etc.). It should be noted that the research was certainly negatively affected by the current Covid-19 situation. We consider it important to state this fact, because the conditions of the research thus gained undesirable limits, for example in the form of a lower sample of respondents, in limiting the possibility of applying a wider battery of methods used with the possibility of increasing research. The research group consisted of 87 primary school children aged $9.57 \pm 0.80$ years ( 43 girls and 44 boys). The results of the research cannot be generalized both with regard to the size of the research group and with regard to the obtained data, because the data did not bring any significant results. We asked two research questions. In the first one we were interested in whether there would be differences in cognitive processes in terms of the presence of fluid intelligence in a group of boys and girls. According to the literature, there are almost traditional differences between these two gender-different groups. Differences in favor of girls are often stated, for example, in connection with school maturity, school performance and motivation for the learning process in primary school conditions (Matějček, 1986; Janošová, 2008; Langmeier, Krejčírová, 2006). Although these differences have not been statistically significant, a closer look at the results (Table 1) shows these traditional differences in all three subtests of the image battery, measuring fluid intelligence. This finding confirms the greater popularity and dexterity of verbal expression in girls, a higher ability to concentrate attention and a higher interest in participating in the test situation. It is possible to state the possibility of stronger aspects of cognitive functions in the sense of fluid intelligence in girls, which evokes the potential to learn and solve problems (Ruisel, 2000). Due to the fact that the subject of the research were children in younger school age, ie. "future adults", this seems to be a tendency that permeates the whole ontogenetic development. In this context, some research studies (eg Ruslin, Jelas, \& Rahman, 2011) can be mentioned, which point to a different approach to learning in men and women. For men, the authors point to a superficial approach to study, while women show a higher level of cooperation, higher participation in study and a tendency towards a deeper approach to learning. This confirms Wyrobková (2007) point of view of, who states that femininity and masculinity are, according to the results of many studies, perceived as complementary opposition and have almost universal significance (Williams, Best, 1990; Wojciszke, 2002). In the second research question, we were interested in whether there would be significant differences in cognitive processes in terms of the presence of fluid intelligence in the group of early ( 8 years) and middle school (11 years) children. Even in this case, no significant differences were found. A closer look at the results shows differences in the performance of pupils in individual monitored age categories, but these are comparable to the cognitive development of other pupils of the same age group due to age and norms (Table 2). Thus, it could be stated that the observed group of respondents shows a cognitive development in accordance with the expected age norm, which are basically positive results. If we want to develop a discussion of this finding, it could be stated that the observed younger school age children are able to adequately understand causal and functional relationships. And they are also able to draw conclusions from initial assumptions, offer solutions to problems and adapt to living conditions appropriate to age and finally, that they are able to create something new (Nakonečný, 1997; Plháková, 2003). The subject of the research was the description and subsequent analysis of cognitive processes (fluid intelligence), which some authors understand as an important and supporting construct and so-called executive functions (some authors do not divide these two components and work with them as a whole). In a person's professional and personal life, it is important how a person understands information, how he/she interprets it, what he/she knows about it and what it means to him/her. In everyday life, decisions or judgments are often made on the basis of randomly provided information, without a deeper context. People also often rely on the usual patterns and stereotypes they follow, even though they may lead to a wrong conclusion. It seems that the systematic collection of information necessary for quality decisions is for some reason unsympathetic and people choose a simpler or more intuitive way (Plháková, 2003; Vágnerová, 2007). So it is an attempt to get out of an unpleasant situation or to get something positive, and we usually have to overcome various obstacles. Numerous findings on problem-solving strategies come from the research of Allen Newell and Herbert A. Simon (1972) (in Plháková, 2003; Atkinson, 2003; Vágnerová, 2007). From a global point of view, the construct of cognitive processes-fluid intelligence is one of the interesting factors, whose further research can co-create a solid basis for answers to teachers' questions on how to proceed in the pedagogical process for the benefit of students. 


\section{REFERENCE LIST}

Atkinson, R. L., Atkinson, R. C., Bem, D. J., Nolen-Hoeksema, S., Smith, E. E. (2003).

Psychologie. Praha: Portál.

Donald E. Knuth, D.,E. (1998). The Art of Computer Programming, Vol 1-3, Addison Wesley.

Erikson, E. H. (2015). Životní cyklus rozšiřrený a dokončený: Devět věků člověka. Praha: Portál.

Fontana, D. (2003). Psychologie ve školní praxi. Praha: Portál.

Hartl, P., Hartlová, H. (2015). Psychologický slovník. Praha: Portál.

Janošová, P. (2008). Dívčí a chlapecká identita. Praha: Grada.

Křeménková, L. (2019). Nahlédnutí do obecné psychologie. In Pugnerová, M. a kolektiv. Psychologie pro pedagogické fakulty. Praha: Grada publishing.

Kuric, J. (1986). Ontogenetická psychologie. Praha: Státní pedagogické nakladatelství.

Langmeier, J., Krejčírová, D. (2006). Vývojová psychologie. Praha: Portál.

Macek, P. (2003). Adolescence. 2., upr. vyd. Praha: Portál.

Matějček, Z. (1986). Rodiče a děti. Praha: Avicenum.

Nakonečný, M. (1997). Encyklopedie obecné psychologie. Praha: Academia.

Nakonečný, M. (2009). Psychologie osobnosti. Praha: Academia.

Nakonečný, M. (2015). Obecná psychologie. Praha: Triton.

Plháková, A. (2003). Učebnice obecné psychologie. Praha: Grada.

Piaget, J. (1999). Psychologie inteligence. Vyd. 2. Praha: Portál.

Piaget, J. a Inhelder, B.(2014). Psychologie dítěte. Vyd. 6. Praha: Portál.

Plháková, A. (2003). Učebnice obecné psychologie. Praha: Grada.

Praus, P. Inteligence a její měření. Časopis Mensy České republiky[online]. 2008.[cit. 2012-12-23]. Dostupné na WWW:<http://casopis.mensa.cz/veda/inteligence_a_jeji_mereni.html>.

Steven, S. S. (2008). The Algorithm Design Manual. Springer, 2. vydání. ISBN978-1848000698.

Sterneberg. (2009). Kognitivní psychologie. Praha: Portál.

Thorndike, R.,L., Hagen, E. (1997). Cognitive Ability Test (CAT). Brno: Psychodiagnostika s.r.o.

Töpfer, P. (1995). Algoritmy a programovací techniky. Prometheus.

Tversky, A., Kahneman, D. (2012). Úsudek v podmínkách nejistoty: heuristiky a zkreslení. In: Kahneman, D. Myšlení -rychlé a pomalé. Brno: Jan Melvil.

Ruisel, I. (2000). Základy psychologie inteligence. Praha: Portál.

Ruisel, I. (2004). Inteligencia a myslenie. Bratislava: Ikar.

Vágnerová, M. (1999). Vývojová psychologie. Praha: Karolinum.

Vágnerová, M. (2005). Vývojová psychologie I.: Dětství a dospívání. Praha: Karolinum.

Vágnerová, M. (2007). Základy psychologie. Praha: Karolinum.

Williams, J., E., Best, D., L. (1990). Measuring sex stereotypes: A multinational study. Newbury park. CA. Sage.

Wojciszke, B. (2002). Kobiety i mezczyzni: odmienne spojrzenia na roznice. Gdansk. GWP.

Wyrobková, A. (2007). Genderový vývoj: nejvýznamnější teorie a výzkum. Československá Psychologie; 51, 2; ProQuest Central pg. 141. 